\title{
Komunikasi Antarpribadi Pedagang-Pedagang Etnis Tionghoa di Kawasan Pasar Pagi Lama
}

\author{
Patricia Frederika, Eko Harry Susanto \\ patricia.915150032@stu.untar.ac.id,ekos@fikom.untar.ac.id
}

Fakultas Ilmu Komunikasi Universitas Tarumanagara

\begin{abstract}
This study discusses about interpersonal communication that occurred between Chinese ethnic merchants in Pasar Pagi Lama area. The majority of merchants in Pasar Pagi Lama area are from Chinese ethnic, which means they are come from the same cultural background. However, even though they generally come from the same ethnicity, each of them has a different tribes, which is they have their own language and folkways. This study used the theory of interpersonal communication, the attraction of similarity, language, folkways and interpersonal relationship. This study used a qualitative approach methodology with a type of descriptive research and with case study research method. The method of data collection in this study used the method of interviews, non-participant observation, literature study and online data search. The conclusion from this study is the interpersonal communication that occurred between Chinese ethnic merchants in Pasar Pagi Lama area goes well even though they have a different tribes. They also still maintaining and build a good relationships through adjusting the language and still doing the folkways in Chinese cultural, which is the folkways on Chinese New Year. In addition, there is no feel that more interest with merchants from the same ethnic or tribes.
\end{abstract}

Keywords: Interpersonal Communication, Chinese Ethnic Merchant, Pasar Pagi Lama

\begin{abstract}
Abstrak
Penelitian ini membahas mengenai komunikasi antarpribadi yang terjadi di antara pedagangpedagang etnis Tionghoa di kawasan Pasar Pagi Lama. Mayoritas pedagang di kawasan Pasar Pagi Lama berasal dari etnis Tionghoa, yang berarti mereka berasal dari latar belakang budaya yang sama. Namun, meskipun secara garis besar mereka berasal dari etnis yang sama, masing-masing dari mereka memiliki kesukuan yang berbeda, yang mana mereka memiliki bahasa dan kebiasaannya masing-masing. Penelitian ini menggunakan teori komunikasi antarpribadi, daya tarik kesamaan, bahasa, kebiasaan dan hubungan antarpribadi. Penelitian ini menggunakan pendekatan kualitatif dengan jenis penelitian yang bersifat deskriptif dan dengan metode penelitian studi kasus. Metode pengumpulan data dalam penelitian ini menggunakan metode wawancara, observasi non-partisipan, studi kepustakaan dan penelusuran data online. Penelitian ini menemukan bahwa komunikasi antarpribadi yang terjadi pada pedagang-pedagang etnis Tionghoa di kawasan Pasar Pagi Lama berjalan dengan baik meskipun memiliki perbedaan suku. Mereka juga tetap saling menjaga dan membangun hubungan yang baik melalui penyesuaian bahasa dan kebiasaan dalam budaya Tionghoa yang masih dilakukan, yaitu kebiasaan pada saat Hari Raya Tahun Baru Imlek. Selain itu, juga tidak ada rasa ketertarikan yang lebih kepada pedagang yang berasal dari etnis ataupun suku yang sama.
\end{abstract}

Kata Kunci: Komunikasi Antarpribadi, Pedagang Etnis Tionghoa, Pasar Pagi Lama 


\section{Pendahuluan}

Sebagai makhluk sosial, manusia tidak dapat terlepas dengan komunikasi. Manusia selalu melakukan proses komunikasi satu dengan yang lain untuk memenuhi kebutuhan sosialnya. Komunikasi merupakan sebuah proses penyampaian informasi dari komunikator kepada komunikan. Menurut Deddy Mulyana (2005) (dalam Azeharie, 2015), kata "komunikasi" atau communication dalam Bahasa Inggris berawal dari bahasa Latin "communicare" yang memiliki arti "membuat sama". Secara harafiah arti membuat sama ini dimaknai sebagai membuat sama antara apa yang dimaksudkan atau apa yang diutarakan komunikator dengan lawan bicaranya yaitu komunikan sehingga terjadi persamaan makna antara komunikator dengan komunikan.

Dalam kehidupan sehari-hari, komunikasi terjadi dimana saja, kapan saja dan dilakukan oleh siapa saja. Misalnya komunikasi antara sesama pedagang di pasar. Komunikasi antara sesama pedagang di pasar ini dapat digolongkan ke dalam komunikasi antarpribadi. Hal ini diperkuat oleh pendapat Berger (dalam West \& Turner 2013) yang menyatakan bahwa komunikasi antarpribadi adalah komunikasi yang terjadi secara langsung antara dua orang. Pada umumnya tujuan utama dari komunikasi antarpribadi adalah untuk saling mengenal, berhubungan dan membantu satu sama lain. Oleh karena itu, komunikasi antarpribadi yang terjadi antara sesama pedagang di pasar bertujuan untuk saling membangun dan menjaga hubungan yang baik.

Pasar pada mulanya hanya dinyatakan sebagai tempat di mana barang-barang diperjual-belikan. Namun, dengan situasi dan perkembangan zaman yang semakin maju, pasar juga dinyatakan sebagai tempat pertemuan untuk saling berinteraksi melalui sebuah komunikasi. Hal ini sejalan dengan pendapat yang dikemukakan oleh Chourmain (dalam Majid, 2014) yang menegaskan bahwa fungsi pasar, terutama pasar bukan hanya sebagai tempat transaksi jual-beli, tetapi juga sebagai media komunikasi antara penjual dan pembeli, pedagang dengan pedagang dan warga masyarakat yang bermukim di sekitar pasar. Pasar menjadi media sosial yang menghubungkan komunikasi antar manusia di suatu daerah.

Komunikasi antarpribadi antara sesama pedagang salah satunya terjadi di kawasan Pasar Pagi Lama, Tambora, Jakarta Barat. Kawasan Pasar Pagi Lama adalah tempat perdagangan (jual-beli) berbagai macam barang dengan harga grosir maupun satuan. Adapun mayoritas pedagang di kawasan Pasar Pagi Lama berasal dari etnis Tionghoa, yang berarti mereka berasal dari latar belakang budaya yang sama. Hal ini menjadi salah satu faktor bagi sesama pedagang etnis Tionghoa di kawasan Pasar Pagi Lama untuk saling berkomunikasi dan membangun sebuah hubungan melalui tahapan-tahapannya. Dengan adanya latar belakang kesamaan etnis biasanya seseorang akan lebih tertarik untuk mengembangkan suatu hubungan dengan orang lain yang memiliki etnis yang sama dengannya. Hal ini karena mereka memiliki latar belakang kebudayaan yang sama, dimana mereka menganut nilai-nilai, sikap, perilaku, kepercayaan dan simbol-simbol yang sama. Manusia pada umumnya menyukai orang yang sama dengan kita dalam hal kebangsaan, suku bangsa, kemampuan, karakteristik fisik, kecerdasan dan khususnya sikap dan selera (DeVito, 2011).

Di dalam suatu hubungan antara sesama etnis yang dibangun melalui sebuah komunikasi antarpribadi terdapat beberapa hal penting yang mendorong terciptanya hubungan yang baik seperti bahasa dan kebiasaan. DeVito menyatakan bahwa bahasa 
dapat dibayangkan sebagai kode atau sistem simbol yang kita gunakan untuk membentuk pesan-pesan verbal kita (DeVito, 2011). Bahasa juga dapat mempersatukan orang-orang dan bahkan membentuk suatu kelompok. Bahasa mengizinkan orang-orang membentuk kelompok dan terlibat dalam usaha yang kooperatif baik dalam skala besar maupun kecil. Memelihara hubungan sosial juga tergantung pada bahasa untuk lebih dari sekadar pesan komunikasi (Samovar, Porter dan McDaniel, 2010). Di Indonesia sendiri etnis Tionghoa dapat terbagi-bagi lagi berdasarkan suku dan bahasa dialek yang digunakannya (bahasa ibu). Terdapat beberapa dialek dalam etnis Tionghoa berdasarkan pada suku yang berbeda-beda, seperti Hokkian, Hakka/Khek, Kanton, Tiochiu dan Hainan. Diperlukan pemahaman kesamaan makna dan simbol-simbol tertentu melalui sebuah bahasa dalam melakukan komunikasi agar komunikasi berjalan secara efektif dan dapat membangun hubungan antarpribadi yang baik.

Hubungan yang terbentuk melalui komunikasi antarpribadi antara pedagangpedagang etnis Tionghoa di kawasan Pasar Pagi Lama juga dipengaruhi oleh kebiasaan dalam budaya Tionghoa yang dilakukan di antara mereka. Sumnner mengartikan kebiasaan atau folkways sebagai aturan adat istiadat yang dapat dilihat dalam pelbagai situasi tertentu, namun tidak cukup kuat untuk mengatur kelompok, dia hanya kebiasaan-kebiasaan saja. Kebiasaan hanya berlaku untuk satu situasi dan waktu tertentu. Kebiasaan merupakan perbuatan yang dilakukan berulang-ulang karena perbuatan itu disukai semua orang (Liliweri, 2009).

Rumusan masalah yang didapatkan dalam penelitian ini adalah bagaimana komunikasi antarpribadi antara pedagang-pedagang etnis Tionghoa di kawasan Pasar Pagi Lama. Tujuan dari penelitian ini adalah untuk mengetahui komunikasi antarpribadi yang terjadi di antara pedagang-pedagang etnis Tionghoa di kawasan Pasar Pagi Lama yang ditinjau dari daya tarik kesamaan, bahasa dan kebiasaan, yang mana ketiga hal tersebut dapat mempengaruhi hubungan antarpribadi melalui komunikasi antarpribadi yang dilakukan.

\section{Metode Penelitian}

Pendekatan penelitian yang penulis gunakan dalam penelitian ini adalah pendekatan kualitatif. Menurut Bogdan dan Taylor (dalam Sujarweni, 2014), penelitian kualitatif adalah salah satu prosedur penelitian yang menghasilkan data deskriptif berupa ucapan atau tulisan dan perilaku orang-orang yang diamati. Jenis penelitian yang digunakan dalam penelitian ini adalah jenis penelitian kualitatif yang bersifat deskriptif. Data deskriptif merupakan data yang dikumpulkan lebih mengambil bentuk kata-kata atau gambar daripada angka-angka. Hasil penelitian tertulis berisi kutipan-kutipan dari data untuk mengilustrasikan dan menyediakan bukti presentasi (Emzir, 2016). Metode penelitian yang digunakan dalam penelitian ini adalah studi kasus. Penelitian studi kasus adalah suatu penelitian kualitatif yang berusaha menemukan makna, menyelidiki proses dan memperoleh pengertian dan pemahaman yang mendalam dari individu, kelompok atau situasi (Emzir, 2016).

Dalam penelitian ini, penulis menggunakan metode pengumpulan data melalui wawancara dengan beberapa narasumber yang dapat memberikan informasi. Narasumber tersebut adalah pedagang-pedagang etnis Tionghoa di kawasan Pasar Pagi Lama dan seorang budayawan Tionghoa yang memahami secara mendalam mengenai etnis Tionghoa dan kebudayaannya. Penulis juga melakukan metode pengumpulan data melalui observasi non-partisipan, studi kepustakaan dan 
penelusuran data online. Observasi non-partisipan yang penulis lakukan ialah melalui pengamatan yang penulis lihat dan dengar dari kejadian secara langsung di lokasi penelitian. Sedangkan metode pengumpulan data melalui studi kepustakaan dan penelusuran data online yang penulis lakukan ialah dengan memanfaatkan bukubuku bacaan atau sumber jurnal ilmiah yang berkaitan dengan bidang Ilmu Komunikasi dan masalah penelitian sebagai sumber data dan landasan teori yang mendukung penelitian ini serta mencari data-data yang diperlukan dalam penelitian ini melalui internet.

Teknik pengolahan dan analisis data yang penulis gunakan dalam penelitian ini ialah menggunakan model interaktif yang dikemukakan oleh Miles dan Huberman (dalam Susanto, 2018) yang menyatakan model analisa data penelitian kualitatif dilakukan melalui proses sebagai berikut: (1) Reduksi data sebagai proses pemilihan, pemusatan perhatian pada penyederhanaan, pengabstrakan dan transformasi data kasar yang muncul dari catatan-catatan tertulis dari lapangan; (2) Penyajian data sebagai sekumpulan informasi tersusun yang memberi kemungkinan adanya penarikan kesimpulan dan pengambilan tindakan; (3) Menarik kesimpulan/verifikasi merupakan kegiatan analisis yang ketiga, dari permulaan pengumpulan data seorang penganalisis kualitatif mulai mencari arti benda-benda, mencatat keteraturan, polapola, penjelasan, konfigurasi alur sebab akibat dan proposisi.

\section{Hasil Temuan dan Diskusi}

Komunikasi antarpribadi terjadi di mana saja, kapan saja dan dilakukan oleh siapa saja, termasuk dilakukan oleh sesama pedagang di pasar. Seperti halnya yang terjadi di antara pedagang-pedagang etnis Tionghoa di kawasan Pasar Pagi Lama yang memang mayoritas pedagangnya berasal dari keturunan etnis Tionghoa, namun berasal dari suku Tionghoa yang berbeda-beda. Pedagang-pedagang etnis Tionghoa di kawasan Pasar Pagi Lama tetap melakukan komunikasi antarpribadi dengan pedagang etnis Tionghoa yang berada di sekitarnya pada waktu senggangnya. Hal ini menunjukkan bahwa memang manusia merupakan makhluk sosial yang terus melakukan komunikasi dan interaksi satu sama lain. Adapun topik yang menjadi pembicaraan mereka cukup beragam, mulai dari topik seputar perdagangan, politik, hingga kehidupan pribadinya masing-masing.

Komunikasi antarpribadi pada umumnya memfokuskan pengamatannya pada bentuk-bentuk dan sifat hubungan/relationship (Susanto, 2018). Dengan adanya komunikasi antarpribadi yang baik dan terus menerus dilakukan antara dua orang, maka akan terjalin suatu hubungan yang semakin erat dengan sendirinya. Hubungan yang terjalin di antara dua orang dapat berkembang ke arah yang baik, jika mereka mengembangkan hubungan yang baik dan dapat juga menuju ke arah yang tidak baik, jika mereka mengalami masalah, konflik yang dapat merusak hubungan mereka. Hubungan yang terjalin di antara pedagang-pedagang etnis Tionghoa di kawasan Pasar Pagi Lama berjalan cukup baik. Dikatakan cukup baik, karena tidak pernah terjadi suatu konflik yang bersifat pribadi. Masalah atau konflik yang terjadi di antara pedagang-pedagang etnis Tionghoa di kawasan Pasar Pagi Lama hanyalah masalah persaingan harga, yang mana hal tersebut merupakan hal yang memang sudah lazim terjadi dalam dunia perdagangan. Melalui konflik persaingan harga yang terjadi, hubungan yang terbentuk paada akhirnya ada yang biasa-biasa saja, tidak sampai terjadi kerusakan hubungan, namun ada juga yang sampai mengalami kerusakan hubungan. Meskipun begitu, secara keseluruhan hubungan yang terjalin di 
antara pedagang-pedagang etnis Tionghoa di kawasan Pasar Pagi Lama berjalan dengan baik, mereka tetap kompak satu sama lain.

Tak hanya menjalin hubungan yang baik saja, pedagang-pedagang etnis Tionghoa di kawasan Pasar Pagi Lama juga bersikap universal dalam komunikasi antarpribadi ataupun pengembangan hubungan. Mereka tidak merasa lebih tertarik untuk hanya berkomunikasi atau mengembangkan hubungan dengan pedagangpedagang yang berasal dari etnis ataupun suku yang sama dengannya. Mereka menganggap semuanya rata dan sama saja.

\section{Tabel 1. Komunikasi Antarpribadi}

\begin{tabular}{ccl}
\hline No. & Komunikasi Antarpribadi & \multicolumn{1}{c}{ Keterangan } \\
\hline 1. & Daya Tarik Kesamaan & Pedagang-pedagang etnis Tionghoa di kawasan \\
& & Pasar Pagi Lama tidak merasa lebih tertarik untuk \\
& hanya berkomunikasi atau mengembangkan \\
& hubungan dengan pedagang-pedagang yang juga \\
& berasal dari etnis atau suku yang sama. \\
& Terjadi konflik persaingan harga di antara beberapa \\
& pedagang etnis Tionghoa di kawasan Pasar Pagi \\
2. Konflik & Lama. Namun, hal ini konflik ini merupakan hal \\
& yang sudah umum terjadi dan biasa-biasa saja. \\
3. Hubungan Antarpribadi & $\begin{array}{l}\text { Hubungan antarpribadi di antara pedagang- } \\
\text { pedagang etnis Tionghoa di kawasan Pasar Pagi }\end{array}$ \\
& Lama umumnya sangat baik. Mereka tetap saling \\
& menjaga hubungan dan tetap kompak satu sama \\
lain.
\end{tabular}

Sumber : Hasil Olah Data Penulis (2018)

Meskipun berasal dari etnis yang sama, bahasa yang digunakan oleh pedagangpedagang etnis Tionghoa saat berkomunikasi di kawasan Pasar Pagi Lama sangat beragam, semua tergantung pada latar belakang suku pedagang etnis Tionghoa tersebut. Seperti yang dikatakan oleh Budayawan Tionghoa yang penulis temui, bahwa tiap-tiap etnis Tionghoa memiliki kesukuan masing-masing, sehingga mereka juga memiliki bahasanya masing-masing.

Pedagang-pedagang etnis Tionghoa di kawasan Pasar Pagi Lama pada umumnya masih menggunakan bahasa ibu dengan dialeknya masing-masing saat melakukan komunikasi antarpribadi dengan pedagang-pedagang etnis Tionghoa lainnya di kawasan Pasar Pagi Lama. Mereka masih menggunakan bahasa ibu, karena mereka memahami dan mengerti bahasa yang berasal dari sukunya masingmasing. Tak hanya bahasa dari suku asalnya saja, terdapat juga beberapa pedagang etnis Tionghoa di kawasan Pasar Pagi Lama yang mengerti bahasa ibu dari suku Tionghoa lainnya. Namun, ada juga pedagang yang berasal dari etnis Tionghoa yang tidak memahami bahasa ibu-nya.

Bahasa ibu yang masih digunakan di kawasan Pasar Pagi Lama di antaranya adalah bahasa Hokkian, Hakka/Khek, Kanton dan Hainan. Meskipun terdapat beragam bahasa di antara pedagang-pedagang etnis Tionghoa di kawasan Pasar Pagi Lama, mereka tetap saling menyesuaikan bahasanya masing-masing saat melakukan komunikasi antarpribadi. Jika salah satu lawan bicaranya atau keduanya tidak mengerti bahasa ibu dari salah satu kesukuan pedagang etnis Tionghoa tersebut, maka mereka menggunakan bahasa Indonesia sebagai sarana mereka untuk berkomunikasi. Tidak ada bahasa yang lebih dominan atau dapat dikatakan tidak ada 
yang membentuk kelompok melalui bahasa ibu-nya atau memaksakan bahasa ibunya untuk digunakan saat melakukan komunikasi antarpribadi.

Tabel 2. Bahasa Pedagang Etnis Tionghoa di Kawasan Pasar Pagi Lama

\begin{tabular}{|c|c|c|}
\hline No. & Bahasa Ibu & Keterangan \\
\hline 1. & Hokkian & $\begin{array}{l}\text { Tidak terjadi dominasi bahasa Hokkian di kawasan Pasar Pagi } \\
\text { Lama. }\end{array}$ \\
\hline 2. & Hakka/Khek & Tidak terjadi dominasi bahasa Hakka di kawasan Pasar Pagi Lama. \\
\hline 3. & Kanton & $\begin{array}{l}\text { Tidak terjadi dominasi bahasa Kanton di kawasan Pasar Pagi } \\
\text { Lama. }\end{array}$ \\
\hline 4. & Hainan & $\begin{array}{l}\text { Tidak terjadi dominasi bahasa Hainan di kawasan Pasar Pagi } \\
\text { Lama. }\end{array}$ \\
\hline
\end{tabular}

Sumber : Hasil Olah Data Penulis (2018)

Selain bahasa dengan dialek-dialek tertentu yang masih digunakan oleh pedagang-pedagang etnis Tionghoa di kawasan Pasar Pagi Lama, kebiasaankebiasaan umum dalam budaya Tionghoa juga masih dilakukan oleh pedagangpedagang etnis Tionghoa di kawasan Pasar Pagi Lama dalam waktu dan situasi tertentu. Kebiasaan tersebut merupakan suatu kegiatan yang dilakukan secara berulang-ulang setiap waktu-waktu tertentu. Kebiasaan-kebiasaan umum dalam budaya Tionghoa yang masih dilakukan oleh pedagang-pedagang etnis Tionghoa di kawasan Pasar Pagi Lama adalah kebiasaan pada saat hari raya tahun baru Imlek, yaitu saling memberikan ucapan selamat hari raya Tahun Baru Imlek dan saling memberikan atau bertukar makanan pada saat hari raya Tahun Baru Imlek.

Tabel 3. Kebiasaan dalam Budaya Tionghoa

\begin{tabular}{ccc}
\hline No. & $\begin{array}{c}\text { Kebiasaan dalam } \\
\text { Budaya Tionghoa }\end{array}$ & \multicolumn{1}{c}{ Keterangan } \\
\hline 1. & $\begin{array}{l}\text { Memberikan Ucapan } \\
\text { pada Hari Raya Tahun } \\
\text { Baru Imlek }\end{array}$ & $\begin{array}{l}\text { Pedagang-pedagang etnis Tionghoa di kawasan Pasar Pagi } \\
\text { Lama masih melakukakn kebiasaan memberikan ucapan } \\
\text { pada Hari Raya Tahun Baru Imlek, yang merupakan hari } \\
\text { besar orang Tionghoa. }\end{array}$ \\
2. & $\begin{array}{l}\text { Memberikan Makanan } \\
\text { pada Hari Raya Tahun } \\
\text { Baru Imlek }\end{array}$ & $\begin{array}{l}\text { Pedagang-pedagang etnis Tionghoa di kawasan Pasar Pagi } \\
\text { Lama juga masih melakukakn kebiasaan saling memberikan } \\
\text { makanan seperti kue-kue pada Hari Raya Tahun Baru Imlek. }\end{array}$ \\
\hline
\end{tabular}

Sumber : Hasil Olah Data Penulis (2018)

Dalam definisi berdasarkan hubungan diadik, komunikasi antarpribadi didefinisikan sebagai komunikasi yang berlangsung di antara dua orang yang mempunyai hubungan yang mantap dan jelas (DeVito, 2011). Komunikasi antarpribadi yang dilakukan oleh pedagang-pedagang etnis Tionghoa di kawasan Pasar Pagi Lama dengan pedagang-pedagang etnis Tionghoa yang berada di sekitarnya berlangsung dengan hubungan yang jelas dan mantap yaitu hubungan sebagai rekan atau teman kerja yang sama-sama berdagang di kawasan Pasar Pagi Lama.

Mayoritas pedagang di kawasan Pasar Pagi Lama adalah pedagang yang berasal dari keturunan etnis Tionghoa. Dalam teori daya tarik kesamaan, DeVito mengatakan bahwa kita umumnya menyukai orang yang sama dengan kita dalam hal kebangsaan, suku bangsa, kemampuan, karakteristik fisik, kecerdasan dan khususnya sikap dan selera (DeVito, 2011). Namun, ternyata hal ini tidak terjadi di kawasan 
Pasar Pagi Lama, karena berdasarkan observasi dan hasil wawancara yang penulis lakukan, pedagang-pedagang etnis Tionghoa di kawasan Pasar Pagi Lama tidak merasa lebih tertarik untuk berkomunikasi atau mengembangkan hubungan yang baik dengan pedagang-pedagang lainnya yang juga berasal dari etnis, suku atau latar belakang yang sama. Mereka tetap membangun hubungan yang baik dengan pedagang-pedagang lainnya yang berasal dari etnis maupun suku yang berbeda dengannya. Adapun hubungan antarpribadi yang terjalin di antara pedagangpedagang etnis Tionghoa di kawasan Pasar Pagi Lama, dapat dikatakan terjalin sangat baik yang dibentuk, dikembangkan dan dijaga melalui sebuah komunikasi antarpribadi yang terjadi di antara mereka.

Hubungan antarpribadi berlangsung melalui lima tahap, yaitu tahap kontak, keterlibatan, keakraban, perusakan dan pemutusan (DeVito, 2011). Namun, berdasarkan data yang penulis dapatkan di lapangan, sebagian besar hubungan antarpribadi pedagang-pedagang etnis Tionghoa di kawasan Pasar Pagi Lama terjalin sangat baik, sehingga dapat dikatakan bahwa hubungan antarpribadi mereka berlangsung hingga tahap ketiga, yaitu keakraban. Sedangkan, untuk pedagang yang mengalami konflik persaingan harga dengan pedagang etnis Tionghoa lainnya hingga membuat hubungan mereka menjadi rusak, dapat dikatakan bahwa hubungan antarpribadinya dengan pedagang lain yang mengalami konflik dengannya sudah berada pada tahap perusakan.

Pedagang-pedagang etnis Tionghoa di kawasan Pasar Pagi Lama berasal dari kesukuan yang berbeda-beda, meskipun secara garis besar mereka sama-sama berasal dari keturunan etnis Tionghoa. Hal ini tentunya mempengaruhi komunikasi yang terjadi di antara mereka, karena masing-masing suku dari etnis Tionghoa memiliki bahasa yang juga berbeda-beda. Menurut Samovar, Porter dan McDaniel, Bahasa mengizinkan orang-orang membentuk kelompok dan terlibat dalam usaha yang kooperatif baik dalam skala besar maupun kecil. Sayangnya, persekutuan yang dibentuk dari bahasa dapat menjadi faktor pemecah ketika manusia mulai mengidentifikasi bahasa ibu mereka terlalu kuat dan merasa terancam oleh bahasa lain (Samovar, Porter dan McDaniel, 2010). Namun, hal ini tidak terjadi di antara pedagang-pedagang etnis Tionghoa di kawasan Pasar Pagi Lama. Meskipun mereka berkomunikasi dengan pedagang etnis Tionghoa yang berasal dari suku yang berbeda dengan dialek bahasa yang berbeda-beda, mereka justru tetap menyesuaikan bahasa yang digunakan. Dialek bahasa yang ada dari berbagai macam suku, tidak menjadi faktor pemecah di antara mereka karena mereka saling menghargai satu sama lain dengan adanya perbedaan dialek bahasa tersebut.

Pedagang etnis Tionghoa di kawasan Pasar Pagi Lama juga masih melakukan beberapa kebiasaan dalam budaya Tionghoa, khususnya pada hari-hari raya besar budaya Tionghoa, seperti Tahun Baru Imlek. Menurut Sumnner mengartikan kebiasaan atau folkways sebagai aturan adat istiadat yang dapat dilihat dalam pelbagai situasi tertentu, namun tidak cukup kuat untuk mengatur kelompok, dia hanya kebiasaan-kebiasaan saja. Kebiasaan hanya berlaku untuk satu situasi dan waktu tertentu. Kebiasaan merupakan perbuatan yang dilakukan berulang-ulang karena perbuatan itu disukai semua orang (Liliweri 2009).

Begitu juga seperti kebiasaan yang dilakukan oleh pedagang-pedagang etnis Tionghoa di kawasan Pasar Pagi Lama. Pada umumnya, mereka melakukan kebiasaan saling memberi ucapan selamat tahun baru Imlek dan saling memberikan atau bertukar makanan seperti kue pada saat tahun baru Imlek. Kebiasaan saling mengucapkan dan memberi makanan pada saat hari raya tahun baru Imlek ini 
memang sudah menjadi kebiasaan etnis Tionghoa sejak dahulu dan masih terus dilakukan hingga saat ini, termasuk pedagang-pedagang etnis Tionghoa di kawasan Pasar Pagi Lama. Kebiasaan-kebiasaan ini terus dilakukan untuk menjaga hubungan antarpribadi mereka agar tetap terjalin dengan baik satu sama lain.

\section{Simpulan}

Komunikasi antarpribadi yang dilakukan oleh pedagang-pedagang etnis Tionghoa di kawasan Pasar Pagi Lama berjalan dengan baik sehingga membentuk hubungan antarpribadi yang baik di antara mereka. Mereka juga tidak merasa lebih tertarik untuk hanya berkomunikasi atau mengembangkan hubungan dengan pedagang-pedagang yang berasal dari etnis atau suku yang sama dengannya. Mereka tetap kompak dan menjaga hubungan baik satu sama lain; Pedagang-pedagang etnis Tionghoa di kawasan Pasar Pagi Lama saling menyesuaikan bahasanya saat melakukan komunikasi antarpribadi. Tidak ada yang memaksakan lawan bicaranya untuk berkomunikasi menggunakan bahasa ibunya, semua menyesuaikan satu sama lain; Pedagang-pedagang etnis Tionghoa di kawasan Pasar Pagi Lama masih melakukan kebiasaan dalam budaya Tionghoa untuk menjaga hubungan yang baik di antara mereka. Kebiasaan tersebut yaitu saling memberikan ucapan dan memberikan makanan pada Hari Raya Tahun Baru Imlek, meskipun kebiasaan tersebut hanya kebiasaan yang memang umum dilakukan.

\section{Ucapan Terima Kasih}

Pada bagian ini, penulis ingin mengucapkan terima kasih kepada seluruh narasumber yang telah bersedia untuk diwawancarai dan memberikan data-data atau informasi yang relevan dengan penelitian ini. Penulis juga mengucapkan terima kasih kepada dosen pembimbing yang telah membimbing dan mengarahkan penulis selama melakukan penelitian ini.

\section{Daftar Pustaka}

Azeharie, Suzy. (2015). Pola Komunikasi Antara Pedagang dan Pembeli di Desa Pare, Kampung Inggris Kediri. Jurnal Komunikasi, 7(2), 207-223.

DeVito, Joseph A. (2011). Komunikasi Antarmanusia. Tangerang: KARISMA Publishing Group.

Emzir. (2016). Metodologi Penelitian Kualitatif: Analisis Data. Jakarta: PT RajaGrafindo Persada.

Liliweri, Alo. (2009). Makna Budaya dalam Komunikasi Antarbudaya. Yogyakarta: LkiS.

Majid, Abdul. (2014). Pasar Sebagai Sarana Komunikasi Antar Budaya (Studi Deskriptif Pedagang Pasar Segiri Samarinda). Jurnal Ilmu Komunikasi, 2(1), 155-165.

West, R., \& Lynn H, Turner. (2013). Pengantar Teori Komunikasi: Analisis dan Aplikasi. Jakarta: Salemba Humanika.

Samovar, Larry A., Porter, Richard E., \& McDaniel, Edwin R. (2010). Komunikasi Lintas Budaya. Jakarta: Salemba Humanika.

Sujarweni, V. Wiratna. (2014). Metodologi Penelitian. Yogyakarta: PUSTAKABARUPRESS. 
Patricia Frederika, Eko Harry Susanto: Komunikasi Antarpribadi Antara Pedagang-Pedagang Etnis

Tionghoa di Kawasan Pasar Pagi Lama

Susanto, Eko Harry. (2018). Komunikasi Manusia: Teori dan Praktik Dalam Penyampaian Gagasan. Jakarta: Mitra Wacana Media. 